\title{
Voltammetric detection of vitamin D employing Au-MoS 2 hybrid as immunosensing platform
}

\author{
Amandeep Kaur ${ }^{1,2} \cdot$ Shilpa Rana $^{1} \cdot$ Anu Bharti ${ }^{1} \cdot$ Ganga Ram Chaudhary ${ }^{2,3} \cdot$ Nirmal Prabhakar $^{1}$ \\ Received: 3 February 2021 / Accepted: 13 May 2021 / Published online: 4 June 2021 \\ (C) The Author(s), under exclusive licence to Springer-Verlag GmbH Austria, part of Springer Nature 2021
}

\begin{abstract}
A voltammetric immunosensor based on molybdenum sulphide $\left(\mathrm{MoS}_{2}\right)$ and gold nanoparticles ( $\mathrm{Au}$ NPs) for the determination of 25-hydroxy vitamin $\mathrm{D}_{3}\left(25(\mathrm{OH}) \mathrm{D}_{3}\right)$ is reported. Anti-vit $\mathrm{D}\left(\mathrm{Ab}-25(\mathrm{OH}) \mathrm{D}_{3}\right)$ was immobilized onto the cysteamine-modified $\mathrm{MoS}_{2}$ and $\mathrm{Au}$ NPs which were deposited onto a fluoride tin oxide (FTO) electrode (Ab/Cys/Au/MoS $/$ /FTO). The MoS 2 sheets were prepared by hydrothermal method followed by an in situ growth of Au film onto the $\mathrm{MoS}_{2} / \mathrm{FTO}$ surface. Self-assembled monolayer (SAM) of cysteamine was synthesized onto the $\mathrm{Au} / \mathrm{MoS}_{2} / \mathrm{FTO}$ which acts as a linker to covalently bind Ab$25(\mathrm{OH}) \mathrm{D}_{3}$. The $\mathrm{Ab}-25(\mathrm{OH}) \mathrm{D}_{3}$-immobilized $\mathrm{Cys} / \mathrm{Au} / \mathrm{MoS}_{2} / \mathrm{FTO}$ was used to detect $25(\mathrm{OH}) \mathrm{D}_{3}$ using differential pulse voltammetry. The electrochemical system provided an anodic peak current at a potential of $+0.21 \mathrm{~V}$ vs. $\mathrm{Ag} / \mathrm{AgCl}$ (satd. $\mathrm{KCl}$ ) of ferricyanide/ferrocyanide redox couple. The detection principle relies on the inhibition of electron transfer at the electrode surface owing to the hindrance caused by the formation of immune complex between $\mathrm{Ab}-25(\mathrm{OH}) \mathrm{D}_{3}$ and $25(\mathrm{OH}) \mathrm{D}_{3}$. The immunosensor shows linear response from $1 \mathrm{pg} \mathrm{mL}^{-1}$ to $100 \mathrm{ng} \mathrm{mL}^{-1} 25(\mathrm{OH}) \mathrm{D}_{3}$ and a sensitivity of $189 \mu \mathrm{A}\left[\mathrm{log}\left(\mathrm{pg} \mathrm{mL}^{-1}\right)\right]^{-1} \mathrm{~cm}^{-2}$ along with a low limit of detection (LOD) of $0.38 \mathrm{pg} \mathrm{mL}^{-1}$. The immunosensor is highly selective towards $25(\mathrm{OH}) \mathrm{D}_{3}$ and presented a long shelf life of 28 days. Also, the immunosensor exhibits satisfactory performance towards spiked human serum samples with recovery between 95.1 and $102 \%$ (RSD $1.15-3.22 \%$ ).
\end{abstract}

Keywords Molybdenum sulphide $\cdot$ Vitamin D $\cdot$ Electrochemical biosensor $\cdot$ Differential pulse voltammetry $\cdot$ Gold nanoparticles · Cysteamine

\section{Introduction}

The widespread prevalence of vitamin D deficiency and recent evidence of its co-relationship with various non-skeletal fatal diseases such as cancer, heart disease, depression, and type 1 diabetes has led to its emergence as a major global health concern $[1,2]$. Additionally, the low serum levels of vitamin

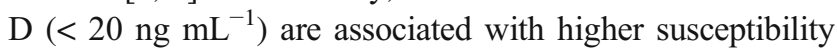
towards respiratory problems which in turn can elevate the mortality rate due to COVID-19 infection [3]. Therefore, vitamin D supplementation is a key element for the prevention

Nirmal Prabhakar

nirmalprabhakar@gmail.com; nirmalprabhakar@pu.ac.in

1 Department of Biochemistry, Panjab University, Chandigarh 160014, India

2 Department of Chemistry and Centre for Advanced Studies in Chemistry, Panjab University, Chandigarh 160014, India

3 SAIF/CIL, Panjab University, Chandigarh 160014, India and management of various chronic diseases, resulting in an increased demand for regular monitoring of vitamin D levels in patients. Despite of efforts being made for incorporation of vitamin D dosage to combat with various ailments, a precise and reliable method for vitamin $\mathrm{D}$ estimation is still a challenge [4].

The conventional methods for the estimation of serum 25 hydroxy vitamin D $(25(\mathrm{OH}) \mathrm{D})$ levels, the major circulating form of vitamin D, are HPLC-MS, radioimmunoassay (RIA), and chemiluminescence [5]. HPLC-MS method is a gold standard method which is efficient to detect vitamin D up to femtomolar concentrations and can distinguish between the two forms of vitamin D: $25(\mathrm{OH}) \mathrm{D}_{2}$ and $25(\mathrm{OH}) \mathrm{D}_{3}$. With such a remarkable sensitivity, HPLC-MS method still suffers with the major limitation of interference of the isobaric coionized components present in the sample. Moreover, the HPLC-MS method is quite expensive and time consuming, hence, not specifically suitable for routine analysis [6]. RIA is highly sensitive and the most used method for clinical analysis of vitamin D, but its high cost and the disposal of 
radioactive waste are the major challenge [7]. Further, chemiluminescence is a user-friendly method as it allows the direct detection of vitamin $\mathrm{D}$ from the sample eliminating the tedious extraction procedure. Nevertheless, the only limiting factor is its inability to detect $25(\mathrm{OH}) \mathrm{D}_{2}$ which is crucial for the overall assessment of vitamin D status [8]. Furthermore, some of the reports suggest that these methods give fallacious and unreliable results $[9,10]$. Hence, it is paramount to have accurate, quick, and reliable method for vitamin D testing which is easily affordable.

Biosensors can provide us a user-friendly, precise, and inexpensive technique with the possibility to perform point-ofcare diagnosis which could considerably shorten the analysis time and open the prospect for on-site monitoring of vitamin D [11]. Presently, only few electrochemical biosensing strategies for the detection of vitamin $\mathrm{D}$ have been explored. Carlucci et al. presented a pioneering report on electrochemical sensing of $25(\mathrm{OH}) \mathrm{D}_{3}$ utilizing gold screen-printed electrode modified with 4-ferrocenylmethyl-1,2,4-triazoline-3,5dione for the detection of $25(\mathrm{OH}) \mathrm{D}_{3}$. The biosensor presented a linear range of $20-200 \mathrm{ng} \mathrm{mL}^{-1}$ with LOD of $10 \mathrm{ng} \mathrm{mL}^{-1}$ [8]. Sarkar et al. described an electrochemical sensor with carbon dots/chitosan-modified ITO (indium tin oxide) surface as an immunosensing platform. The biosensor possesses $1.35 \mathrm{ng} \mathrm{mL}^{-1}$ LOD and a linear response within 10 $50 \mathrm{ng} \mathrm{mL}{ }^{-1}$ [12]. Another report on electrochemical immunosensing of $25(\mathrm{OH}) \mathrm{D}_{3}$ was published by Chauhan et al. They designed a bioelectrode based on $\mathrm{Fe}_{3} \mathrm{O}_{4}$ /polyacrylonitrile fiber composite which could detect $25(\mathrm{OH}) \mathrm{D}_{3}$ up to $0.12 \mathrm{ng} \mathrm{mL}^{-1}$ with a linear range of $10-100 \mathrm{ng} \mathrm{mL}^{-1}$ [13]. Furthermore, Chauhan et al. presented an electrochemical detection of vitamin D employing BSA/Ab-VD/Asp$\mathrm{Gd}_{2} \mathrm{O}_{3} \mathrm{NRs} / \mathrm{ITO}$ immunoelectrode obtaining LOD of $0.10 \mathrm{ng} \mathrm{mL}^{-1}$ and linear range within $10-100 \mathrm{ng} \mathrm{mL}^{-1}$ [14]. In our previous attempt, a Au-Pt NPs supported on 3-(aminopropyl)triethoxysilane-modified FTO (fluoride tin oxide) electrode as a biosensing platform for the electrochemical detection of $25(\mathrm{OH}) \mathrm{D}_{3}$ was designed. The LOD was $0.49 \mathrm{pg} \mathrm{mL}^{-1}$ with stability of 10 days [15]. Herein, we have designed a strategy to further improve the analytical performance of the biosensor for detection of $25(\mathrm{OH}) \mathrm{D}_{3}$.

Two dimensional materials such as $\mathrm{MoS}_{2}$ and graphene are being extensively used in electrochemical biosensing due to their excellent electro-catalytic performance, ease of synthesis, high surface area, and tremendous physicochemical properties [16, 17]. Govindasamy et al. employed glassy carbon electrode modified with $\mathrm{MoS}_{2}$-graphene nanocomposite for sensitive amperometric determination of methyl parathion up to $3.2 \mathrm{nM}$ concentration [18]. In another report, Govindasamy et al. reported an electrochemical determination of chloramphenicol based on $\mathrm{MoS}_{2}$ nanosheet-coated functionalized multiwalled carbon nanotubes (MWCNTs) hybrid. They further stated that $\mathrm{MoS}_{2}$-MWCNTs hybrid possesses excellent electro-catalytic property towards chloramphenicol [19]. Despite of various properties, the low conductivity of $\mathrm{MoS}_{2}$ limits its utility in electrochemical sensing [20]. To overcome this, the in situ growth of Au NPs onto the $\mathrm{MoS}_{2}$ film could be a potential solution as this not only improves the conductivity but also provides additional mechanical strength by utilizing the novel Au-S interaction [21, 22]. In this context, Sreeprasad et al. presented a mechanistic approach towards incorporating $\mathrm{Au}$ NPs onto the $\mathrm{MoS}_{2}$ via leveraging the stable sulphur-noble metal interaction [23]. Mani et al. employed graphene nanosheet (GNS)- $\mathrm{MoS}_{2}$ composite as template for the growth of $\mathrm{Au}$ NPs for the electrochemical determination of folic acid which displayed a low LOD of $38.5 \mathrm{nM}$ [24]. Thus, $\mathrm{Au} /$ $\mathrm{MoS}_{2}$ composite holds superior electro-catalytic properties, high conductivity, and biocompatibility, owing to the synergistic effect of both $\mathrm{MoS}_{2}$ and Au, making it highly effective electrochemical platform [25]. Based on this, the present work describes the estimation of $25(\mathrm{OH}) \mathrm{D}_{3}$ using cysteamine modified $\mathrm{Au} / \mathrm{MoS}_{2} / \mathrm{FTO}$ electrode. SAM of cysteamine was synthesized onto the $\mathrm{Au} / \mathrm{MoS}_{2} / \mathrm{FTO}$ electrode surface to ensure robust and directional binding of $\mathrm{Ab}-25(\mathrm{OH}) \mathrm{D}_{3}[26]$.

\section{Experimental section}

\section{Materials}

All the chemicals were of analytical grade and were used as obtained without any prior purification. Sodium bicarbonate $\left(\mathrm{NaHCO}_{3}, \geq 99 \%\right)$, bovine serum albumin (BSA), buffer RWT (wash buffer), 3,3',5,5'tetramethyl benzidine, sodium molybdate hydrate $\left(\mathrm{Na}_{2} \mathrm{MoO}_{4} \cdot \mathrm{H}_{2} \mathrm{O}\right)$, thiourea $\left(\mathrm{SC}\left(\mathrm{NH}_{2}\right)_{2}\right)$, hydroxylamine solution $\left(\mathrm{NH}_{2} \mathrm{OH}\right)(50 \%)$, chloroauric acid $\left(\mathrm{HAuCl}_{4}\right)$ (99\% pure), $25(\mathrm{OH}) \mathrm{D}_{3}$ ( $\geq 99 \%$ HPLC grade purity), dimethyl formamide (DMF), hydroxyl amine (50 wt\%), human serum, cysteamine solution, citric acid, absolute ethanol, and FTO were purchased from Sigma Aldrich, USA. Mouse monoclonal $\mathrm{Ab}-25(\mathrm{OH}) \mathrm{D}_{3}$ and HRP-linked anti-rabbit ( $\operatorname{IgG})$ secondary antibodies were purchased from GeneTex Inc., USA. Sodium dihydrogen orthophosphate dihydrate $\left(\mathrm{NaH}_{2} \mathrm{PO}_{4} \cdot 2 \mathrm{H}_{2} \mathrm{O}\right)$ and disodium hydrogen orthophosphate anhydrous $\left(\mathrm{Na}_{2} \mathrm{HPO}_{4}\right)$ were procured from Thermo Fisher Scientific Pvt. Ltd., Mumbai, India. Potassium ferricyanide $\left(\mathrm{K}_{3} \mathrm{Fe}(\mathrm{CN})_{6}\right)(99 \%)$, potassium ferrocyanide trihydrate $\left(\mathrm{K}_{4} \mathrm{Fe}(\mathrm{CN})_{6} .3 \mathrm{H}_{2} \mathrm{O}\right)(99 \%)$, hydrochloric acid, and sodium hydroxide pellets (98\%) were purchased from HiMedia Laboratory Pvt. Ltd., Mumbai, India. The $\mathrm{Ab}-25(\mathrm{OH}) \mathrm{D}_{3}$ solution was prepared in $0.1 \mathrm{M}$ phosphate buffer (PB) $(780 \mathrm{mg}$ $\mathrm{NaH}_{2} \mathrm{PO}_{4} \cdot 2 \mathrm{H}_{2} \mathrm{O}$ and $708 \mathrm{mg} \mathrm{Na}_{2} \mathrm{HPO}_{4}$ in $50 \mathrm{~mL}$ distilled water) at $\mathrm{pH} 7.4$, and a range of $25(\mathrm{OH}) \mathrm{D}_{3}$ 


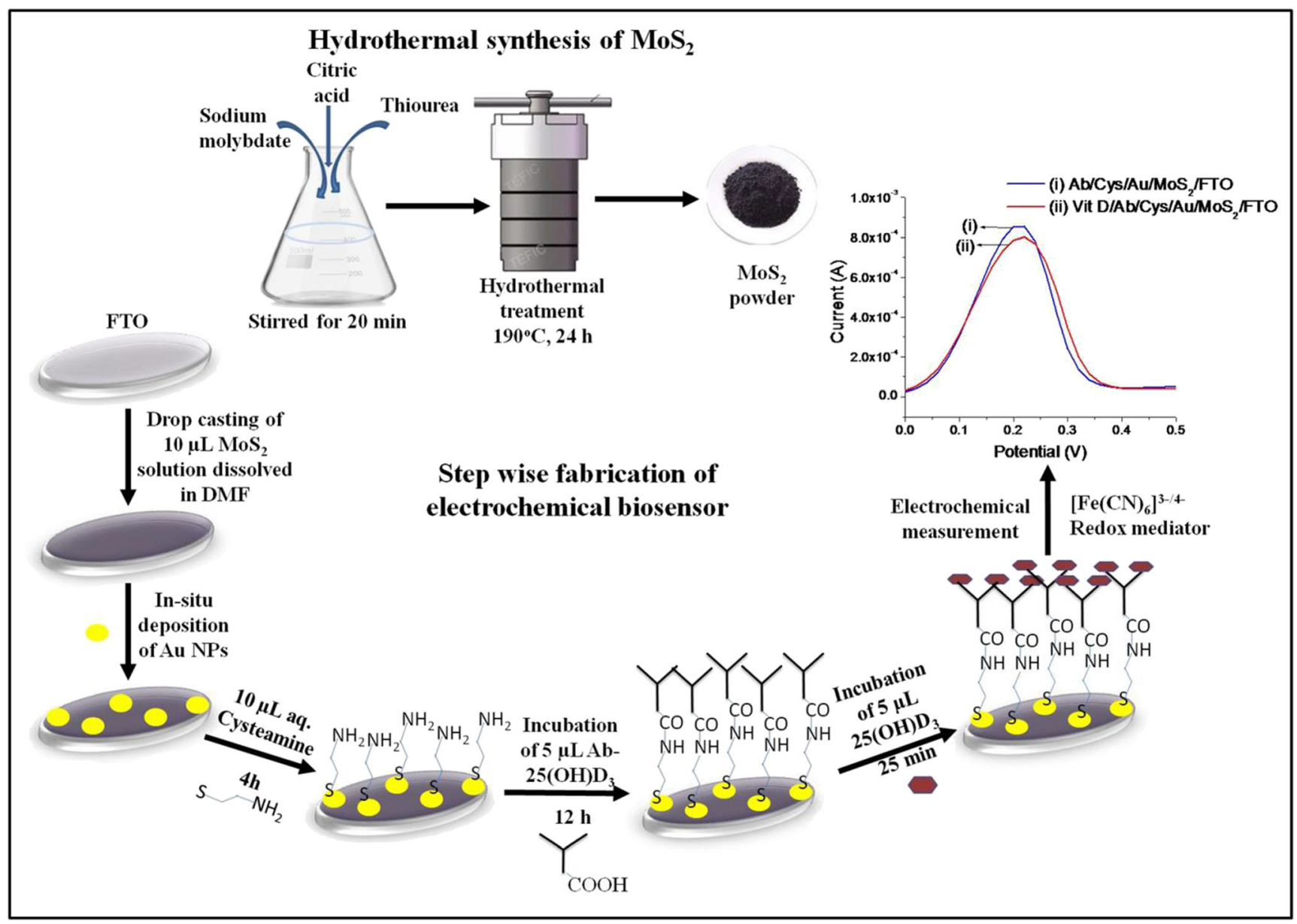

Fig. 1 Schematic illustration of step-wise fabrication of immunosensor for $25(\mathrm{OH}) \mathrm{D}_{3}$ detection

concentrations was prepared by serial dilution method in absolute ethanol as solvent.

\section{Synthesis of $\mathrm{MoS}_{2}$}

$\mathrm{MoS}_{2}$ was prepared by following green hydrothermal method. Sodium molybdate hydrate $(0.43 \mathrm{~g})$ and thiourea $(0.69 \mathrm{~g})$ were dissolved in $80 \mathrm{~mL}$ ultrapure water followed by the addition of citric acid $(0.46 \mathrm{~g})$, and the reaction mixture was stirred continuously for $20 \mathrm{~min}$. The obtained homogeneous solution was allowed to react for $24 \mathrm{~h}$ in $100 \mathrm{~mL}$ teflon-lined stainless steel reactor (autoclave) maintained at $190{ }^{\circ} \mathrm{C}$. The black precipitates formed were washed thoroughly with distilled water and ethanol to remove any unreacted precursor and were left to dry at $70{ }^{\circ} \mathrm{C}$ for $12 \mathrm{~h}$ [27].

\section{Modification of working electrode (FTO) surface}

Prior to the use, FTOs were thoroughly cleaned via sonication in $2 \%$ acetic acid solution for 30 min followed by sonication in ethanol and distilled water for 15 min each. The prepared $\mathrm{MoS}_{2}$ was dissolved in
DMF and was sonicated for $2 \mathrm{~h}$ using probe sonicator (operating at $45 \%$ power of $230 \mathrm{~V}$ input voltage). After the complete dispersion, $10 \mu \mathrm{L}$ of $\mathrm{MoS}_{2}$ solution was drop casted onto the predetermined surface of treated FTO $\left(0.25 \mathrm{~cm}^{2}\right)$ and was dried at room temperature (RT). Further, the Au NPs were deposited onto the $\mathrm{MoS}_{2} / \mathrm{FTO}$ surface by following an in situ approach that involves immersion of the electrode in $1 \mathrm{mM}$ solution of chloroauric acid $(10 \mathrm{~mL})$ followed by addition of $15 \mu \mathrm{L}$ hydroxylamine solution $(50 \mathrm{wt} \%)$ that acts as a mild reducing agent to accelerate the reduction of $\mathrm{Au}$ (III) to $\mathrm{Au}(0)$. The solution was then kept undisturbed

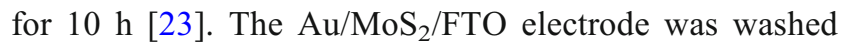
thoroughly by distilled water and left to dry at RT.

\section{Immobilization of bio-recognition element}

Ten microliters of aqueous cysteamine solution $(10 \mathrm{mM})$ was drop casted onto the $\mathrm{Au} / \mathrm{MoS}_{2} / \mathrm{FTO}$ electrode for $4 \mathrm{~h}$ at RT. Cysteamine acts as a bi-functional agent, $-\mathrm{SH}$ group of cysteamine forms SAM on $\mathrm{Au} / \mathrm{MoS}_{2} / \mathrm{FTO}$ electrode, and the free $-\mathrm{NH}_{2}$ group interacts with $-\mathrm{COOH}$ 


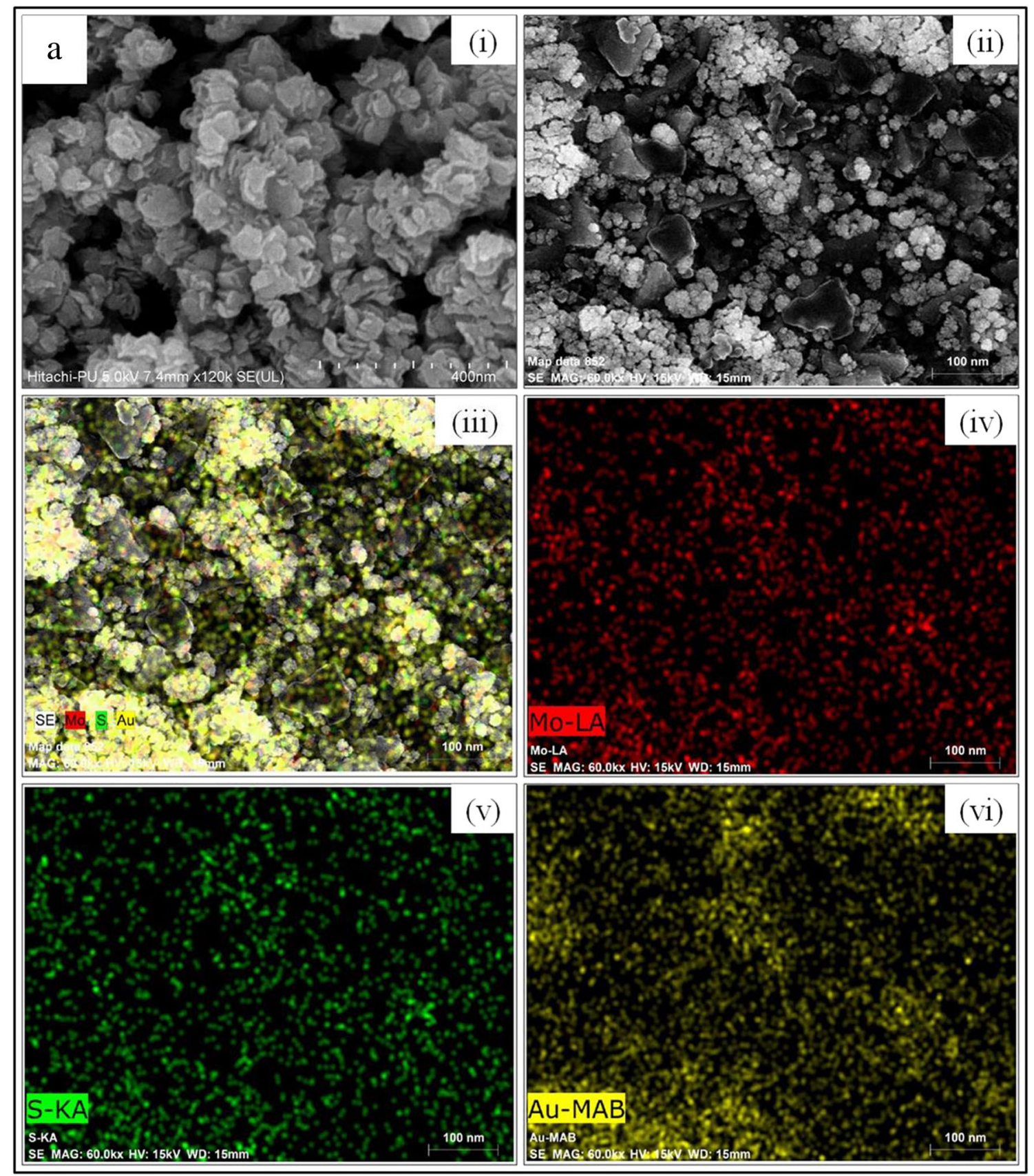

Fig. 2 Surface characterizations: a FESEM images of (i) $\mathrm{MoS}_{2} / \mathrm{FTO}$ and (ii) $\mathrm{Au} / \mathrm{MoS}_{2} / \mathrm{FTO}$ electrode; elemental mapping of $\mathrm{Au} / \mathrm{MoS}_{2} / \mathrm{FTO}$ electrode, representing (iii) $\mathrm{Mo}, \mathrm{S}$ and $\mathrm{Au}$; (iv) $\mathrm{Mo}$; (v) $\mathrm{S}$; and (vi) $\mathrm{Au}$ elements, and b FT-IR spectrum of (i) $\mathrm{MoS}_{2} / \mathrm{FTO}$, (ii) $\mathrm{Au} / \mathrm{MoS}_{2} / \mathrm{FTO}$, (iii) $\mathrm{Cys} / \mathrm{Au} / \mathrm{MoS}_{2} / \mathrm{FTO}$, and (iv) $\mathrm{Ab} / \mathrm{Cys} / \mathrm{Au} / \mathrm{MoS}_{2} / \mathrm{FTO}$

immunoelectrodes were stored at $4{ }^{\circ} \mathrm{C}$, while not in use. Figure 1 represents the schematic illustration of step-wise fabrication of immunosensor.

\section{Characterization of immobilization matrix}

The electrodes were characterized by Fourier transform infrared spectroscopy (FT-IR) (Nicolet 1S50 FTIR), field emission 


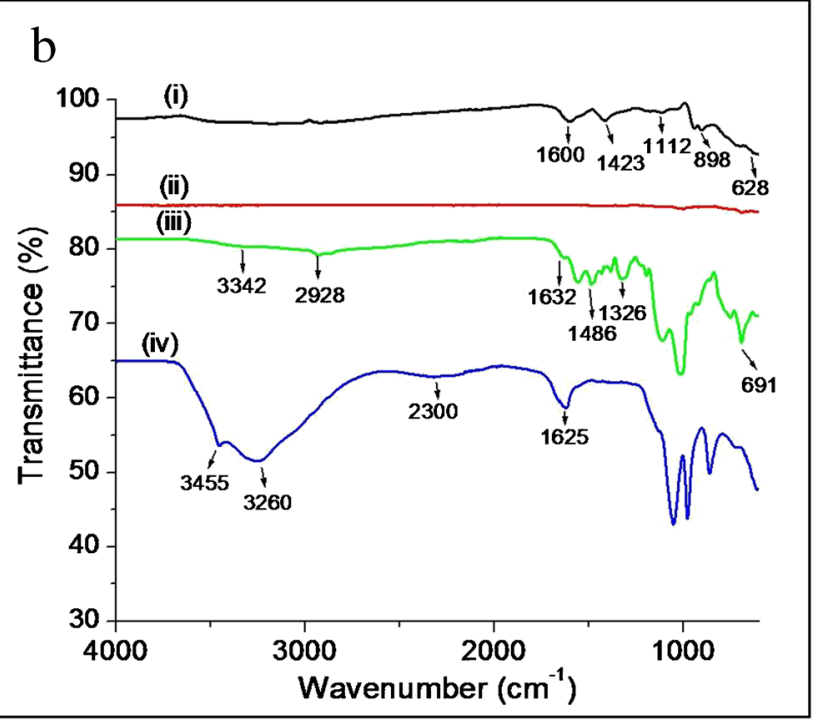

Fig. 2 (continued)

scanning electron microscopy (FE-SEM), energy dispersive spectroscopy (EDS, Hitachi SU 8010), X-ray diffraction [XRD, Panalytical X'Pert Pro X-Ray Diffractometer using $\mathrm{CuK} \alpha$ as radiation $(\lambda=1.54 \AA)$, and contact angle measurement [Sessile drop (KRÜSS apparatus)]. To evaluate the electrochemical behavior of electrodes, electrochemical characterizations such as cyclic voltammetry (CV), differential pulse voltammetry (DPV), and electrochemical impedance spectroscopy (EIS) were carried out on Autolab Potentiostat/Galvanostat [AutoLab 302NFRA32M]. The electrochemical studies were conducted using a threeelectrode system. The potential of the working electrode (modified FTO) was measured with respect to the reference electrode, i.e., $\mathrm{Ag} / \mathrm{AgCl}$ (satd. $\mathrm{KCl}$ ), and $\mathrm{Pt}$ wire was used as a counter electrode. All electrochemical studies $(\mathrm{CV}$, DPV, and EIS) were performed in $5 \mathrm{mM}$ ferricyanide/ ferrocyanide redox probe prepared in $50 \mathrm{mM}$ PB with $0.9 \% \mathrm{NaCl}$ as an electrolyte and $\mathrm{pH}$ 7.4. Each DPV measurement was carried out by keeping the step potential $0.02 \mathrm{~V}$, modulation amplitude $0.1 \mathrm{~V}$, and modulation time $0.05 \mathrm{~s}$ with an interval of $0.5 \mathrm{~s}$. All electrochemical experiments were performed in triplicates, and error bars represent the standard deviation of three independent set of experiments

To confirm the binding of $\mathrm{Ab}-25(\mathrm{OH}) \mathrm{D}_{3}$ with $25(\mathrm{OH}) \mathrm{D}_{3}$, ELISA was performed. The detailed description of ELISA procedure is given in electronic supplementary material (Section 4, Fig. S4, Table S1).

\section{Electro-active surface area}

The effect of the surface modifications on the electroactive surface area of the electrodes was evaluated by performing cyclic voltammetry at different scan rates $(v)$ ranging from 10 to $100 \mathrm{mV} \mathrm{s}^{-1}$ in $5 \mathrm{mM}\left[\mathrm{Fe}(\mathrm{CN})_{6}\right]^{3-/ 4-}$ solution at each modification step. The variation of oxidation peak current $\left(I_{p a}\right)$ with increasing scan rate was examined, and the electro-active surface area was obtained using Randles-Sevcik equation [29] as described below:

$I_{p a}=2.69 \times 10^{5} \mathrm{~A} \mathrm{n}^{3 / 2} \mathrm{C} \mathrm{D}_{\mathrm{r}}{ }^{1 / 2} v^{1 / 2}$

Here, $I_{p a}$ is the oxidation peak current (A) and $v$ represents the scan rate $\left(\mathrm{V} \mathrm{s}^{-1}\right)$.

$\mathrm{A}$ is the electro-active surface area in $\mathrm{cm}^{2}$

$\mathrm{n}$ is the number of electrons involved in redox reaction $(n=1)$

$\mathrm{C}$ represents the concentration of redox species, i.e., $\left[\mathrm{Fe}(\mathrm{CN})_{6}\right]^{3-4 /-}\left(5 \times 10^{-6} \mathrm{~mol} \mathrm{~cm}^{-3}\right)$

$\mathrm{D}_{\mathrm{r}}$ is the diffusion coefficient $\left(7.6 \times 10^{-6} \mathrm{~cm}^{2} \mathrm{~s}^{-1}\right)$

The electro-active surface area was procured by interpreting the slope of the plot between $\mathrm{I}_{\mathrm{pa}}$ and $v^{1 / 2}$ for each modification at the electrode surface.

\section{Optimization of method}

Prior to the electrochemical sensing studies, the following parameters were optimized: (a) $\mathrm{pH}$ of $\mathrm{PB}$, (b) concentration of $\mathrm{Ab}-25(\mathrm{OH}) \mathrm{D}_{3}$ to be immobilized, and (c) response time required for interaction of $\mathrm{Ab}-25(\mathrm{OH}) \mathrm{D}_{3}$ with $25(\mathrm{OH}) \mathrm{D}_{3}$. Respective texts and figures are given in electronic supplementary material (Section 1, Fig. S1). In short, the following experimental conditions were found to give best results: (a) $\mathrm{PB} \mathrm{pH}=7.4$, (b) concentration of $\mathrm{Ab}-25(\mathrm{OH}) \mathrm{D}_{3}=$ $15 \mu \mathrm{g} \mathrm{mL}^{-1}$, and (c) response time $=25 \mathrm{~min}$.

\section{Electrochemical detection procedure}

Various dilutions of stock $25(\mathrm{OH}) \mathrm{D}_{3}$ solution $\left(1 \mathrm{mg} \mathrm{mL}^{-1}\right)$, i.e., $1 \mathrm{pg} \mathrm{mL}^{-1}, 10 \mathrm{pg} \mathrm{mL}^{-1}, 100 \mathrm{pg} \mathrm{mL}^{-1}, 1 \mathrm{ng} \mathrm{mL}^{-1}$, $10 \mathrm{ng} \mathrm{mL}^{-1}, 100 \mathrm{ng} \mathrm{mL}^{-1}$, and $1 \mu \mathrm{g} \mathrm{mL}^{-1}$, were prepared in absolute ethanol. For electrochemical detection of $25(\mathrm{OH}) \mathrm{D}_{3}$, $10 \mu \mathrm{L}$ of predetermined concentration of $25(\mathrm{OH}) \mathrm{D}_{3}$ solution was incubated onto the $\mathrm{Ab} / \mathrm{Cys} / \mathrm{Au} / \mathrm{MoS}_{2} / \mathrm{FTO}$ electrode for $25 \mathrm{~min}$ at room temperature, and three independent electrodes were prepared for each concentration. After this, the electrode was washed three times with PB to remove loosely bound target molecules and subjected to DPV measurements. The DPV studies were carried out using $\mathrm{Ag} / \mathrm{AgCl}$ (satd. $\mathrm{KCl}$ solution) as reference electrode and $\mathrm{Pt}$ wire as counter electrode in $5 \mathrm{mM}\left[\mathrm{Fe}(\mathrm{CN})_{6}\right]^{3-/ 4-}$ solution (pH 7.4) containing $0.9 \%$ $\mathrm{KCl}$ within potential window from 0.0 to $1.2 \mathrm{~V}$. The variation in anodic peak current for different concentrations of $25(\mathrm{OH}) \mathrm{D}_{3}$ was analyzed to obtain the limit of detection, sensitivity, and linear response range. 

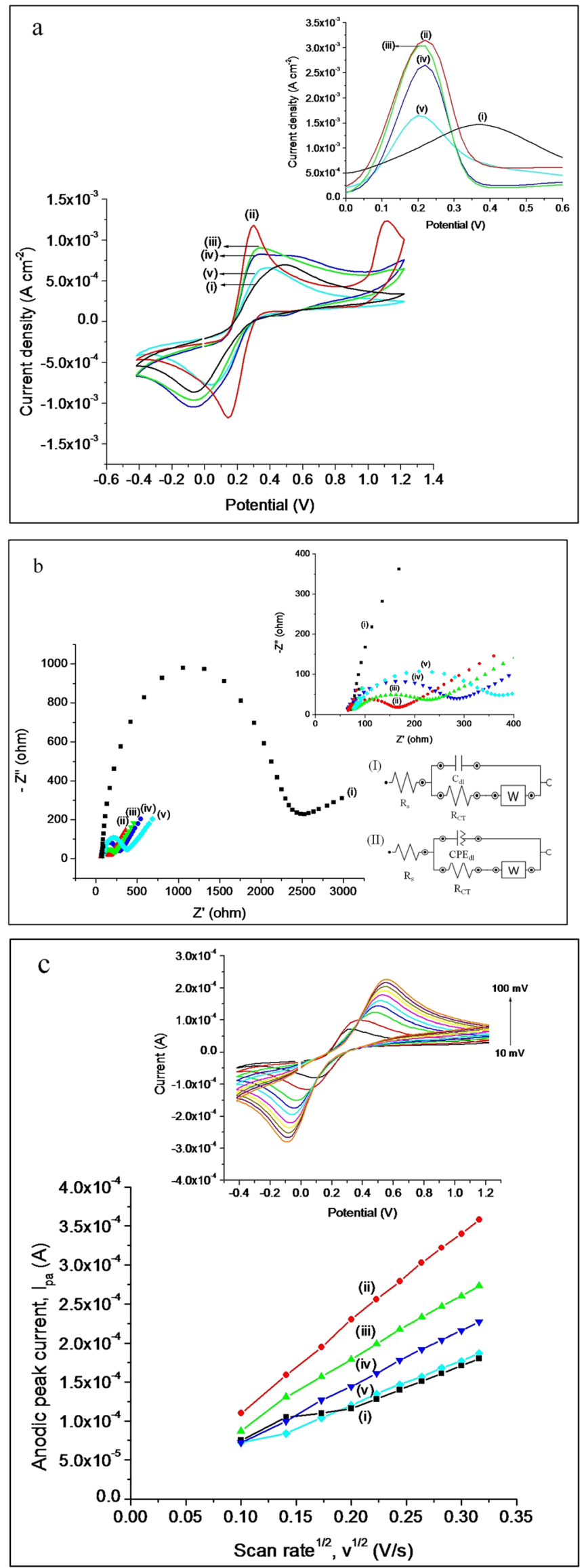
Fig. 3 Electrochemical characterizations: (i) $\mathrm{MoS}_{2} / \mathrm{FTO}$, (ii) $\mathrm{Au} / \mathrm{MoS}_{2} / \mathrm{FTO}$, (iii) $\mathrm{Cys} / \mathrm{Au} / \mathrm{MoS}_{2} / \mathrm{FTO}$, (iv) $\mathrm{Ab} / \mathrm{Cys} / \mathrm{Au} / \mathrm{MoS}_{2} / \mathrm{FTO}$, and (v) VitD/Ab/Cys/ $\mathrm{Au} / \mathrm{MoS}_{2} / \mathrm{FTO}$ using a CV measurements at a scan rate of $50 \mathrm{mV} \mathrm{s}^{-1}$; inset shows the DPV response at step potential of $0.02 \mathrm{~V}$ with modulation amplitude of $0.1 \mathrm{~V}$; $\mathbf{b}$ Nyquist plot recorded over a frequency range of $0.1-10^{5} \mathrm{~Hz}$ at open circuit potential; inset represents the (I) Randles equivalent circuit and (II) equivalent circuit; and $\mathbf{c}$ the plot of Ipa vs. ${ }^{1 / 2}$ at each modification step; inset represents the $\mathrm{CV}$ response of $\mathrm{Au} / \mathrm{MoS}_{2} / \mathrm{FTO}$ electrode at scan rates ranging from 10 to $100 \mathrm{mV} \mathrm{s}^{-1}$, all in $5 \mathrm{mM}\left[\mathrm{Fe}(\mathrm{CN})_{6}\right]^{3-/ 4-}$ redox couple prepared in $50 \mathrm{mM} \mathrm{PB}(\mathrm{pH} 7.4,0.9 \% \mathrm{KCl})$

\section{Analytical performance of electrochemical biosensor}

The variation from electrode to electrode was evaluated by performing reproducibility analysis. The reproducibility was checked by preparing two sets of $\mathrm{Ab} / \mathrm{Cys} / \mathrm{Au} / \mathrm{MoS}_{2} / \mathrm{FTO}$ electrodes, each containing five immunoelectrodes incubated with $1 \mathrm{ng} \mathrm{mL} L^{-1}$ and $10 \mathrm{ng} \mathrm{mL}^{-1}$ concentration of $25(\mathrm{OH}) \mathrm{D}_{3}$, respectively. After washing with $\mathrm{PB}$, the electrodes were subjected to DPV studies. The peak current value in DPV was evaluated to test the reproducibility of biosensor. To check the stability of the immunosensor, a set of $\mathrm{Ab} / \mathrm{Cys} / \mathrm{Au} / \mathrm{MoS}_{2} / \mathrm{FTO}$ electrode was preserved at $4{ }^{\circ} \mathrm{C}$ for 35 days, and DPV experiment was conducted for three electrodes each time at an interval of 7 days. Further, the effect of various interferents such as glucose $(4 \mathrm{mM})$, cholesterol $(4 \mathrm{mM})$, oxalic acid $(1 \mathrm{mM})$, uric acid $(0.5 \mathrm{mM})$, and $25(\mathrm{OH}) \mathrm{D}_{2}\left(25 \mathrm{ng} \mathrm{mL}^{-1}\right)$ on electrochemical determination of $25(\mathrm{OH}) \mathrm{D}_{3}$ was studied by taking the concentrations equivalent to their abundance in the serum. For selectivity study, a fixed volume $(10 \mu \mathrm{L})$ of each of these interferents was mixed with the same amount of $25(\mathrm{OH}) \mathrm{D}_{3}$ $\left(25 \mathrm{ng} \mathrm{mL}^{-1}\right)$. The resultant solution was allowed to react with immunoelectrodes for $25 \mathrm{~min}$, and after washing with PB, DPV analysis was performed. Experiment was performed in triplicate. For better comparison, the DPV response of the blank immunoelectrode and the immunoelectrode incubated with $25(\mathrm{OH}) \mathrm{D}_{3}\left(25 \mathrm{ng} \mathrm{mL}^{-1}\right)$ was also registered.

\section{Spike in studies}

To assess the applicability of the immunosensor in serum samples, immunoelectrodes were tested by estimation of $25(\mathrm{OH}) \mathrm{D}_{3}$ concentration in spiked human serum samples. The various concentrations of $25(\mathrm{OH}) \mathrm{D}_{3}\left(1,10,10^{2}, 10^{3}\right.$, and $10^{4} \mathrm{pg} \mathrm{mL}^{-1}$ ) were spiked into standard $10 \% \mathrm{v} / \mathrm{v}$ diluted human serum in $\mathrm{PB}(\mathrm{pH}$ 7.4). The spiked samples $(5 \mu \mathrm{L})$ were incubated onto the $\mathrm{Ab} / \mathrm{Cys} / \mathrm{Au} / \mathrm{MoS}_{2} / \mathrm{FTO}$ electrode, each in triplicate, for $25 \mathrm{~min}$, and DPV measurement was performed after washing with PB. Further, the peak current value was noted, and it was compared with the standard calibration plot in order to calculate the recovery percentage by implying the following formula:

\section{Concentration found}

$$
\begin{aligned}
= & (\text { spiked sample peak current/standard peak current }) \\
& \times \text { concentration spiked }
\end{aligned}
$$

Recovery\%

$$
=(\text { concentration found } / \text { concentration spiked }) \times 100
$$

\section{Results and discussions}

\section{Choice of materials}

Layered materials such as carbon nitride, graphene, and $\mathrm{MoS}_{2}$ have been widely explored in the field of electrochemical sensing. Among these, $\mathrm{MoS}_{2}$ has attracted immense attention owing to its porous structure, tunable band gap, and high adsorption capability. Furthermore, it provides a robust platform for further incorporation of NPs [30]. Despite of its various unique properties, $\mathrm{MoS}_{2}$ suffers from a major drawback of lower conductivity. To overcome this limitation, gold NPs have been in situ grown on the surface of $\mathrm{MoS}_{2}$ film. Au/ $\mathrm{MoS}_{2}$ composite imparts excellent conductivity and enhanced robustness to the immunosensor owing to the strong affinity of Au towards the sulphur atom which significantly promotes the strength of the immobilization matrix [22]. A selfassembled monolayer of cysteamine was also introduced onto the $\mathrm{Au} / \mathrm{MoS}_{2} / \mathrm{FTOs}$ to allow the chemical binding of $\mathrm{Ab}$ $25(\mathrm{OH}) \mathrm{D}_{3}$ via amide bond formation between amine group of cysteamine and carboxylic group at Fc region of antibody. This not only allows the chemical binding of antibody onto the electrode surface but also promotes its controlled and directional binding rendering the antigen binding site of antibody free for efficient interaction with analyte [28].

\section{Surface characterization studies}

The morphological features of the modified electrodes were assessed by FESEM analysis. The FESEM image of $\mathrm{MoS}_{2} /$ FTO (Fig. 2a (i)) shows a well-dispersed sheet-like structure indicating the formation of $\mathrm{MoS}_{2}$ sheets. The scattered round structures obtained in FESEM image of $\mathrm{Au} / \mathrm{MoS}_{2} / \mathrm{FTO}$ electrode (image ii) depict the deposition of Au NPs over the surface of $\mathrm{MoS}_{2} / \mathrm{FTO}$ electrode. This is attributed to the high affinity of Au towards the $\mathrm{S}$ in $\mathrm{MoS}_{2}$ which leads to uniform distribution of $\mathrm{Au}$ onto the $\mathrm{MoS}_{2} / \mathrm{FTO}$ electrode. Figure 2a (iii)-(vi) shows the elemental mapping of $\mathrm{Au} / \mathrm{MoS}_{2} / \mathrm{FTO}$ electrode [(iii) Mo, S, Au; (iv) Mo; (v) S; and (vi) Au]. The elemental mapping also supports the uniform deposition of $\mathrm{Au}$ with a weight percentage of $27.5( \pm 2.58)$. The composition of the matrix was further confirmed by 

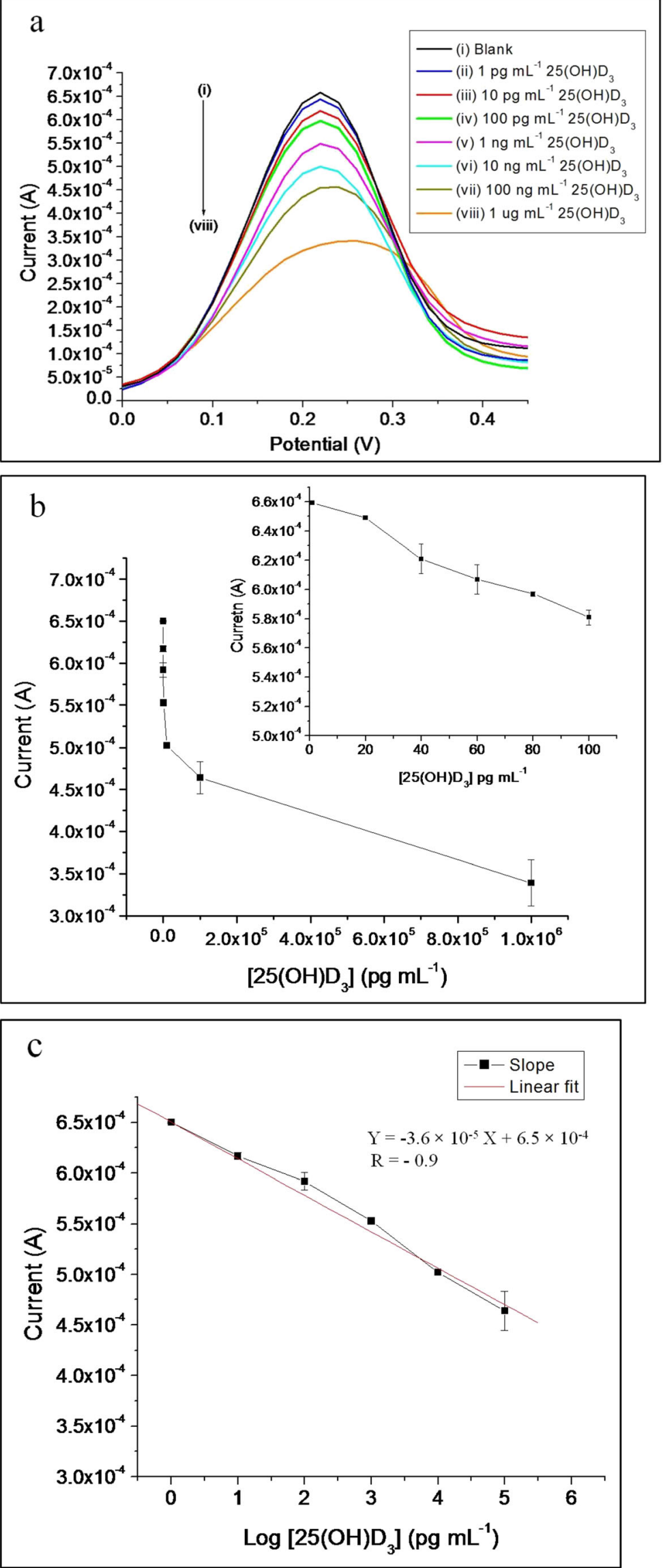
Fig. 4 Electrochemical detection of $25(\mathrm{OH}) \mathrm{D}_{3}$ : a DPV response of immunosensor incubated with different concentrations of $25(\mathrm{OH}) \mathrm{D}_{3}$ [blank (without $25(\mathrm{OH}) \mathrm{D}_{3}$ ) $, 1 \mathrm{pg} \mathrm{mL}^{-1}, 10 \mathrm{pg} \mathrm{mL}^{-1}, 100 \mathrm{pg} \mathrm{mL}^{-1}$, $1 \mathrm{ng} \mathrm{mL}^{-1}, 10 \mathrm{ng} \mathrm{mL}^{-1}, 100 \mathrm{ng} \mathrm{mL}^{-1}$, and $\left.1 \mu \mathrm{g} \mathrm{mL}^{-1}\right]$ in $50 \mathrm{mM} \mathrm{PB}$ containing $5 \mathrm{mM}\left[\mathrm{Fe}(\mathrm{CN})_{6}\right]^{3-/ 4-}$ redox couple $(\mathrm{pH} 7.4,0.9 \% \mathrm{KCl})$, b the variation of peak current value with the concentration of $25(\mathrm{OH}) \mathrm{D}_{3}$ ranging from 1 to $10^{6} \mathrm{pg} \mathrm{mL}^{-1}$; inset represents the change in peak current value for a narrow $25(\mathrm{OH}) \mathrm{D}_{3}$ concentration $\left(1\right.$ to $\left.100 \mathrm{pg} \mathrm{mL}^{-1}\right)$, and $\mathbf{c}$ calibration plot of current vs. $\log$ conc. $25(\mathrm{OH}) \mathrm{D}_{3}$ for which a linear response was obtained at a working potential of $+0.21 \mathrm{~V}$ vs. $\mathrm{Ag} / \mathrm{AgCl}$ (satd. $\mathrm{KCl}$ ) electrode. The error bars show the standard deviation of three independent set of values

EDS and XRD analysis, given in electronic supplementary material (Section 2, Fig. S2).

The FT-IR spectra of $\mathrm{MoS}_{2} / \mathrm{FTO}$ show prominent peaks at $1600,1423,1112,898$, and $628 \mathrm{~cm}^{-1}$ which are the characteristic peaks for $\mathrm{MoS}_{2}$ [31] (Fig. b, curve i). In case of $\mathrm{Au} /$ $\mathrm{MoS}_{2} / \mathrm{FTO}$, no notable peaks were seen that indicates the full coverage of the $\mathrm{MoS}_{2} / \mathrm{FTO}$ electrode surface with the Au NPs (curve ii). In FT-IR spectra of Cys/Au/MoS $/$ FTO (curve iii), the appearance of characteristic peaks at $2928 \mathrm{~cm}^{-1}(\mathrm{C}-\mathrm{H})$, $1486 \mathrm{~cm}^{-1}$ ( $\mathrm{CH}_{2}$ bending), $1326 \mathrm{~cm}^{-1}$ (C-N stretching), 691 (C-S stretching), $3342 \mathrm{~cm}^{-1}$ (N-H stretching), and $1632 \mathrm{~cm}^{-1}$ $\left(\mathrm{NH}_{2}\right.$ group scissoring) substantiate the presence of selfassembled monolayer of cysteamine. Moreover, the absence of stretching peak of S-H bond at about $2260 \mathrm{~cm}^{-1}$ further confirms that there were no free-SH groups present ensuring the efficient interaction of $\mathrm{Au}$ with the - $\mathrm{SH}$ group present in cysteamine [32]. After the introduction of $\mathrm{Ab}-25(\mathrm{OH}) \mathrm{D}_{3}$ onto the $\mathrm{Cys} / \mathrm{Au} / \mathrm{MoS}_{2} / \mathrm{FTO}$ electrode, the signature peak of $\mathrm{N}-\mathrm{H}$ bond stretching at $3260 \mathrm{~cm}^{-1}$ due to the $\mathrm{NH}_{2}$ group present at $\mathrm{Fab}$ region of antibody confirms the presence of $\mathrm{Ab}$ $25(\mathrm{OH}) \mathrm{D}_{3}$ onto the electrode surface. Furthermore, the absorbance peak at $3455 \mathrm{~cm}^{-1}$ (N-H stretching) and $1625 \mathrm{~cm}^{-1}$ (carbonyl group) of amide group validate the covalent binding of $\mathrm{Ab}-25(\mathrm{OH}) \mathrm{D}_{3}$ onto the electrode surface via interaction of $\mathrm{NH}_{2}$ group of cysteamine layer with the carboxyl group which is present at $\mathrm{Fc}$ region of antibody leading to the formation of amide bond. Also, the emergence of peak at $2300 \mathrm{~cm}^{-1}$ corresponding to $\mathrm{C}=\mathrm{N}$ stretching mode confirms the partial double bond character of the amide bond formed (curve iv). The contact angle measurements were also performed to assess the effect of modifications on hydrophilic nature of electrode surface. The detailed description is given in electronic supplementary material (Section 3, Fig. S3).

\section{Electrochemical characterizations}

$\mathrm{CV}$ was performed at a scan rate of $50 \mathrm{mV} \mathrm{s}^{-1}$ and step potential of $0.02 \mathrm{~V}$ within 0.6 to $1.2 \mathrm{~V}$ potential window in $5 \mathrm{mM}$ $\left[\mathrm{Fe}(\mathrm{CN})_{6}\right]^{3-/ 4-}$ solution prepared in $50 \mathrm{mM} \mathrm{PB}(0.9 \% \mathrm{NaCl})$. Figure 3 a depicts the variation of current density $\left(\mathrm{A} \mathrm{cm}^{-2}\right)$ with the applied potential for (i) $\mathrm{MoS}_{2} / \mathrm{FTO}$, (ii) $\mathrm{Au} / \mathrm{MoS}_{2} /$ FTO, (iii) Cys/Au/ $\mathrm{MoS}_{2} / \mathrm{FTO}$, (iv) $\mathrm{Ab} / \mathrm{Cys} / \mathrm{Au} / \mathrm{MoS}_{2} / \mathrm{FTO}$, and (v) Vit D/Ab/Cys/Au/ $/ \mathrm{MoS}_{2} / \mathrm{FTO}$ electrodes. As compared to the $\mathrm{MoS}_{2} / \mathrm{FTO}$ electrode (curve i, $7.0 \times 10^{-4} \mathrm{~A}$ $\mathrm{cm}^{-2}$ ), there was a huge increase in the peak current density (curve ii, $1.2 \times 10^{-3} \mathrm{~A} \mathrm{~cm}^{-2}$ ) upon deposition of Au NPs which conveys an enhanced electron transfer kinetics between the working electrode and $\left[\mathrm{Fe}(\mathrm{CN})_{6}\right]^{3-/ 4-}$ redox probe. Furthermore, a gradual decrease in the anodic peak current density has been observed upon introduction of cysteamine (curve iii, $9.1 \times 10^{-4} \mathrm{~A} \mathrm{~cm}^{-2}$ ), Ab-25(OH) $\mathrm{D}_{3}$ (curve iv, $8.3 \times$ $10^{-4} \mathrm{~A} \mathrm{~cm}^{-2}$ ), and $25(\mathrm{OH}) \mathrm{D}_{3}$ (curve v, $6.6 \times 10^{-4} \mathrm{~A} \mathrm{~cm}^{-2}$ ). This is ascribed to the non-conductive nature of these proteins creating a hindrance to the flow of electrons, hence, resulting in reduced electro-catalytic property of electrode towards the redox reaction. Also, the electrochemical behavior of

Table 1 Comparison of analytical performance of current immunosensor with the previously reported sensors

\begin{tabular}{|c|c|c|c|c|c|}
\hline Nanocomposite & Analyte & LOD & Linearity range & Shelf life & Reference \\
\hline $\mathrm{MPA}^{\mathrm{a}} / \mathrm{Au} \mathrm{SPE}^{\mathrm{b}}$ & $25(\mathrm{OH}) \mathrm{D}_{3}$ & $10 \mathrm{ng} \mathrm{mL}^{-1}$ & $20-200 \mathrm{ng} \mathrm{mL}^{-1}$ & - & [8] \\
\hline Carbon dots/chitosan/ITO ${ }^{c}$ & $25(\mathrm{OH}) \mathrm{D}_{2}$ & $1.35 \mathrm{ng} \mathrm{mL}^{-1}$ & $10-50 \mathrm{ng} \mathrm{mL}^{-1}$ & 25 days & [12] \\
\hline $\mathrm{Fe}_{3} \mathrm{O}_{4} /$ polyacrylonitrile fibers/ITO & $25(\mathrm{OH}) \mathrm{D}_{3}$ & $0.12 \mathrm{ng} \mathrm{mL}^{-1}$ & $10-100 \mathrm{ng} \mathrm{mL}^{-1}$ & - & {$[13]$} \\
\hline Asp- $\mathrm{Gd}_{2} \mathrm{O}_{3} \mathrm{NRs} / \mathrm{ITO}$ & $25(\mathrm{OH}) \mathrm{D}_{3}$ & $0.10 \mathrm{ng} \mathrm{mL}^{-1}$ & $10-100 \mathrm{ng} \mathrm{mL}^{-1}$ & 56 days & [14] \\
\hline Glut $^{\mathrm{d}} / \mathrm{Au}-\mathrm{Pt} / \mathrm{APTES}^{\mathrm{e}} / \mathrm{FTO}^{\mathrm{f}}$ & $25(\mathrm{OH}) \mathrm{D}_{3}$ & $0.49 \mathrm{pg} \mathrm{mL}^{-1}$ & $0.1-10^{6} \mathrm{pg} \mathrm{mL}^{-1}$ & 10 days & {$[15]$} \\
\hline $\mathrm{Cys}{ }^{\mathrm{g}} / \mathrm{Au} / \mathrm{MoS}_{2} / \mathrm{FTO}$ & $25(\mathrm{OH}) \mathrm{D}_{3}$ & $0.38 \mathrm{pg} \mathrm{mL}^{-1}$ & $1-10^{5} \mathrm{pg} \mathrm{mL}^{-1}$ & 28 days & [Current study] \\
\hline
\end{tabular}

${ }^{\text {a } M P A}$ mercaptopropionic acid

${ }^{\mathrm{b}} \mathrm{A} u$ SPE gold screen-printed electrode

${ }^{\mathrm{c}}$ ITO indium tin oxide

${ }^{\mathrm{d}}$ Glut glutaraldehyde

${ }^{\mathrm{e}}$ APTES 3-aminopropyltriethoxysilane

${ }^{\mathrm{f}}$ FTO fluorine tin oxide

${ }^{\mathrm{g}}$ Cys cysteamine 

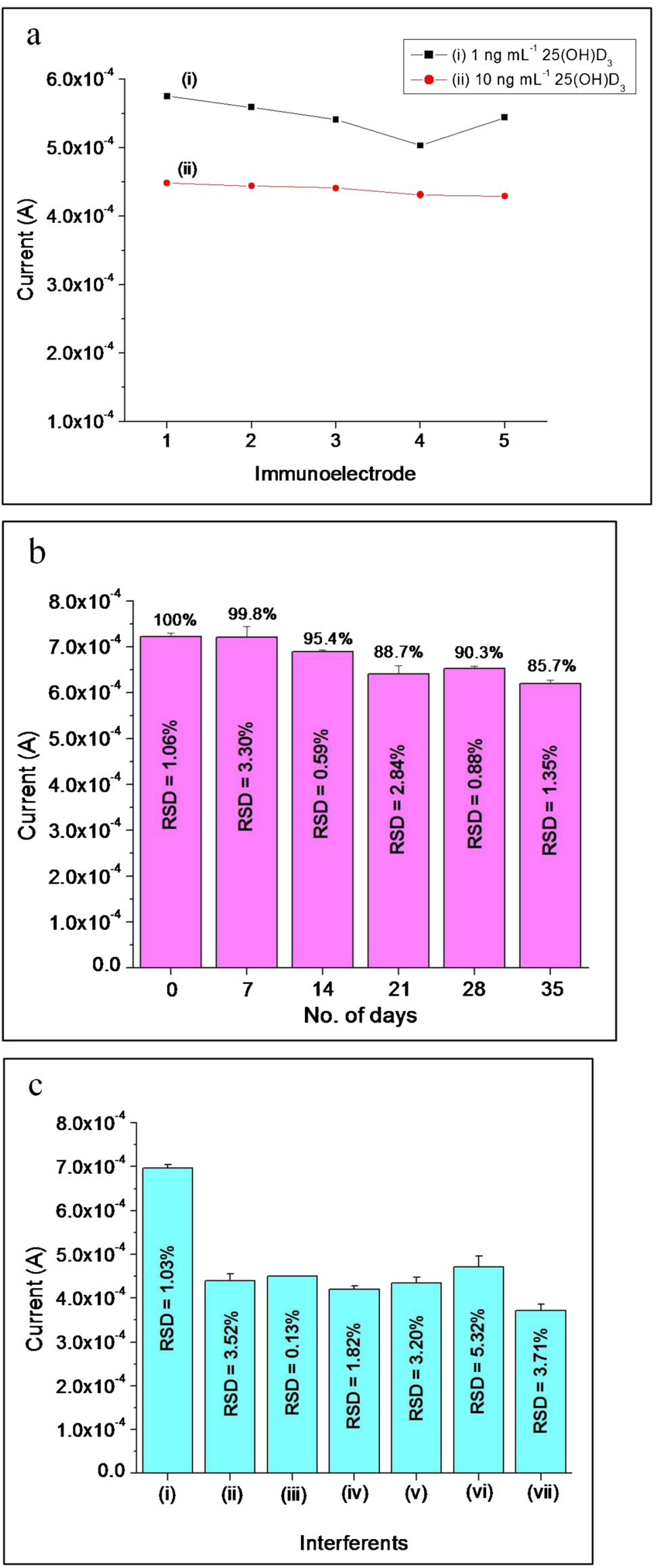
Fig. 5 a Reproducibility study: DPV response of two sets of five independent $\mathrm{Ab} / \mathrm{Cys} / \mathrm{Au} / \mathrm{MoS}_{2} / \mathrm{FTO}$ electrodes incubated with (i) $1 \mathrm{ng} \mathrm{mL}^{-1}$ and (ii) $10 \mathrm{ng} \mathrm{mL}^{-1} 25(\mathrm{OH}) \mathrm{D}_{3}$, respectively; b stability study: peak current value of DPV measurements of $\mathrm{Ab} / \mathrm{Cys} / \mathrm{Au} / \mathrm{MoS}_{2} / \mathrm{FTO}$ electrode for 35 days at an interval of 7 days $(n=3)$; and $\mathbf{c}$ selectivity study: peak current value of DPV measurements of $\mathrm{Ab} / \mathrm{Cys} / \mathrm{Au} / \mathrm{MoS}_{2} / \mathrm{FTO}$ immunoelectrode incubated with (i) blank, (ii) $25(\mathrm{OH}) \mathrm{D}_{3}\left(25 \mathrm{ng} \mathrm{mL}^{-1}\right)$, (iii) $25(\mathrm{OH}) \mathrm{D}_{3}+$ glucose $(4 \mathrm{mM})$, (iv) $25(\mathrm{OH}) \mathrm{D}_{3}+$ cholesterol $(4 \mathrm{mM})$, (v) $25(\mathrm{OH}) \mathrm{D}_{3}+$ oxalic acid $(1 \mathrm{mM}),(\mathrm{vi}) 25(\mathrm{OH}) \mathrm{D}_{3}+\operatorname{uric}$ acid $(0.5 \mathrm{mM})$, and (vii) $25(\mathrm{OH}) \mathrm{D}_{3}+25(\mathrm{OH}) \mathrm{D}_{2}\left(25 \mathrm{ng} \mathrm{mL}^{-1}\right)$. Each study was performed in triplicates in $50 \mathrm{mM} \mathrm{PB}(\mathrm{pH} 7.4,0.9 \% \mathrm{KCl})$ containing $5 \mathrm{mM}\left[\mathrm{Fe}(\mathrm{CN})_{6}\right]^{3-/ 4-}$, and $\mathrm{RSD}$ value corresponds to the deviation in response of three independent measurements

modified electrodes was further investigated by DPV analysis under similar electrochemical conditions. Inset of Fig. 3a represents the DPV response at each modification step. The details are discussed in electronic supplementary material (Section 5). Importantly, the DPV results well comply with the cyclic voltammogram obtained for modified electrodes pointing towards the successful formation of immobilization matrix.

EIS studies were also conducted within the frequency range $0.1-10^{5} \mathrm{~Hz}$ and operating at open circuit potential in $5 \mathrm{mM}\left[\mathrm{Fe}(\mathrm{CN})_{6}\right]^{3-/ 4-}$ solution. The EIS data was interpreted in terms of Nyquist plot (Fig. 3b), and equivalent circuit (inset to Fig. 3b) was fitted to extract the parameters such as solution resistance $\left(R_{s}\right)$, charge transfer resistance $\left(R_{C T}\right)$, capacitance of constant phase element which is a representative of double layer capacitance at the interface $\left(\mathrm{CPE}_{\mathrm{dl}}\right)$, double layer capacitance of capacitor indicating electrode-electrolyte interface $\left(\mathrm{C}_{\mathrm{d} 1}\right)$, and Warburg impedance $(\mathrm{W})$. The Randles circuit (Fig. 3b (I)) explains the Nyquist plot (i), whereas the Nyquist plots (ii)-(v) are represented by modified equivalent circuit (Fig. 3b (II)). The electrical parameters obtained are given in electronic supplementary material (Table S2). The $\mathrm{R}_{\mathrm{CT}}$ value follows the trend; $\mathrm{MoS}_{2} / \mathrm{FTO}(2110 \pm 4.43 \Omega)>$ $\mathrm{Vit} \mathrm{D} / \mathrm{Ab} / \mathrm{Cys} / \mathrm{Au} / \mathrm{MoS}_{2} / \mathrm{FTO}(308 \pm 6.11 \Omega)>\mathrm{Ab} / \mathrm{Cys} / \mathrm{Au} /$ $\mathrm{MoS}_{2} / \mathrm{FTO}(224 \pm 6.80 \Omega)>\mathrm{Cys} / \mathrm{Au} / \mathrm{MoS}_{2} / \mathrm{FTO}(194 \pm$ $3.11 \Omega)>\mathrm{Au} / \mathrm{MoS}_{2} / \mathrm{FTO}(112 \pm 1.40 \Omega)$. It is noteworthy that the Au film considerably decreased the impedance at electrode surface which is attributed to its high conductivity, facilitating the electron transfer at electrode-electrolyte interface. Further,

Table 2 Recovery studies of $25(\mathrm{OH}) \mathrm{D}_{3}$ in spiked human serum samples $(n=3)$

\begin{tabular}{lllll}
\hline S. No. & $\begin{array}{l}\text { Conc. of spiked } \\
\text { sample }\left(\mathrm{pg} \mathrm{mL} \mathrm{m}^{-1}\right)\end{array}$ & $\begin{array}{l}\text { Conc. found } \\
\left(\mathrm{pg} \mathrm{mL}^{-1}\right)\end{array}$ & Recovery (\%) & RSD (\%) \\
\hline 1. & 1 & 0.997 & 99.7 & 2.02 \\
2. & 10 & 10.2 & 102 & 3.22 \\
3. & $10^{2}$ & 95.1 & 95.1 & 1.26 \\
3. & $10^{3}$ & 982 & 98.2 & 1.15 \\
4. & $10^{4}$ & 9954 & 99.5 & 1.40 \\
\hline
\end{tabular}
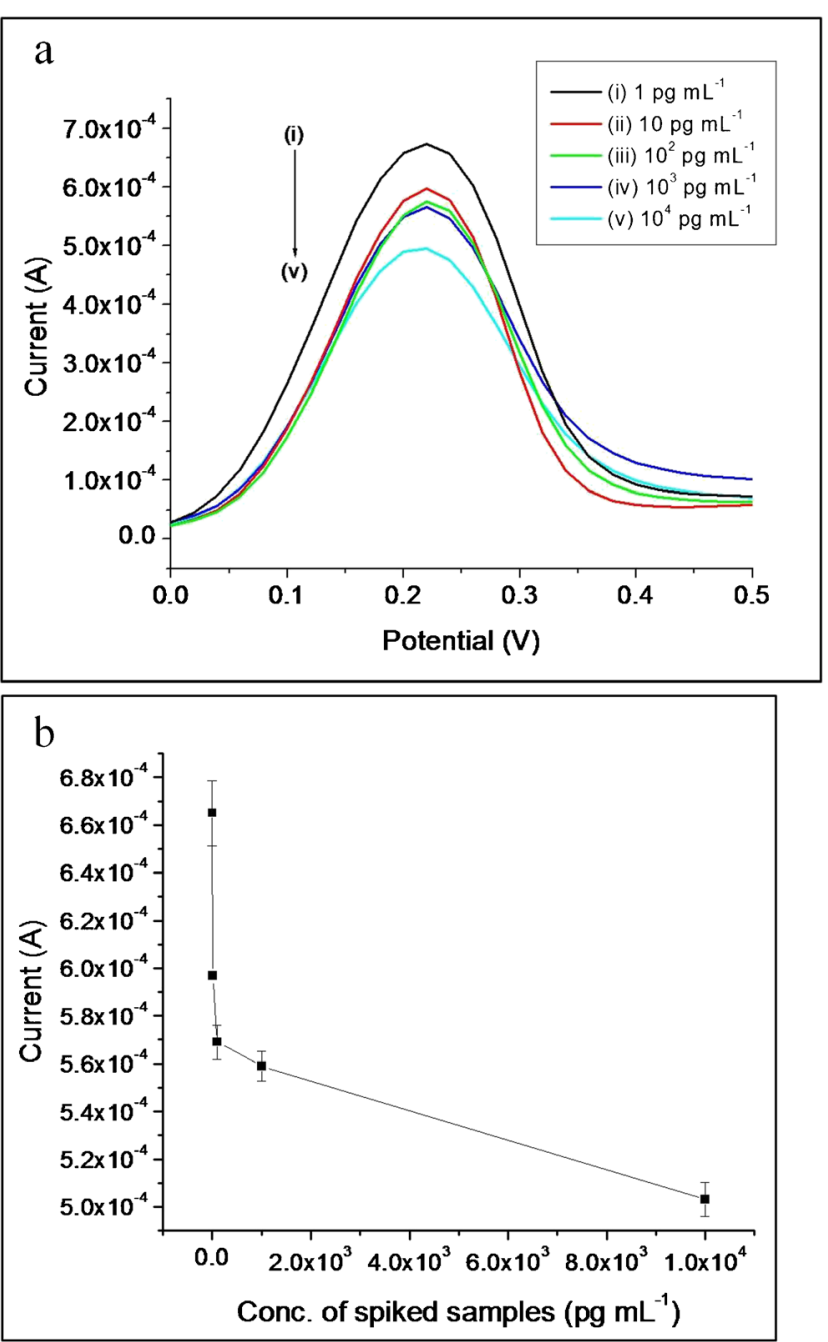

Fig. 6 Electrochemical detection of $25(\mathrm{OH}) \mathrm{D}_{3}$ in spiked samples: a DPV response of $\mathrm{Ab} / \mathrm{Cys} / \mathrm{Au} / \mathrm{MoS}_{2} / \mathrm{FTO}$ electrode incubated with spiked human serum with different concentrations of $25(\mathrm{OH}) \mathrm{D}_{3}\left(1,10,10^{2}\right.$, $10^{3}$, and $\left.10^{4} \mathrm{pg} \mathrm{mL}^{-1}\right)$ in $5 \mathrm{mM}\left[\mathrm{Fe}(\mathrm{CN})_{6}\right]^{3-/ 4-}$ solution containing $0.9 \% \mathrm{KCl}$ maintained at $\mathrm{pH} 7.4$ and $\mathbf{b}$ calibration plot of peak current value vs. spiked concentration of $25(\mathrm{OH}) \mathrm{D}_{3}$ for $\mathrm{n}=3$

the formation of SAM of cysteamine on $\mathrm{Au} / \mathrm{MoS}_{2}$ electrode hindered the electrode surface which is supported by the increase in $\mathrm{R}_{\mathrm{CT}}$ value. Furthermore, an increase in $\mathrm{R}_{\mathrm{CT}}$ value upon coating of $25(\mathrm{OH}) \mathrm{D}_{3}$ was observed. This rise in $\mathrm{RCT}$ value is indicative of formation of immune-complex between $\mathrm{Ab}-25(\mathrm{OH}) \mathrm{D}_{3}$ and $25(\mathrm{OH}) \mathrm{D}_{3}$ which prohibits the diffusion of $\left[\mathrm{Fe}(\mathrm{CN})_{6}\right]^{3-/ 4-}$ redox probe towards the electrode surface.

\section{Electro-active surface area}

The dependence of anodic peak current on the scan rate was evaluated. Figure $3 \mathrm{c}$ inset clearly depicts that the anodic peak current increases linearly with the increase in the scan rate which is the characteristic of diffusion controlled redox reaction. Also, the oxidation potential and reduction potential shift towards more 
positive and negative values, respectively, as the scan increases, which indicates smooth electron transfer kinetics.

Figure $3 \mathrm{c}$ represents the plot of anodic peak current vs. (scan rate) ${ }^{1 / 2}$ for modified electrodes indicating a linear variation of anodic peak current with scan rate. By fitting the linear equation, the value of slope and intercept was obtained which was further implied to calculate electro-active surface area. The Randles-Sevcik equations obtained by incorporating the values are as follows:

$$
\begin{aligned}
\mathrm{I}_{\mathrm{pa}(\mathrm{MoS} 2 / \mathrm{FTO})=} & \left(4.60 \times 10^{-4} \mathrm{~A} \mathrm{Vs}^{-1}\right) v^{1 / 2} \\
& +30.4 \mu \mathrm{A}, \mathrm{R} \\
=0.98 &
\end{aligned}
$$

$\mathrm{I}_{\mathrm{pa}}(\mathrm{Au} / \mathrm{MoS} 2 / \mathrm{FTO})$

$$
\begin{aligned}
=\left(11.5 \times 10^{-4} \mathrm{~A} \mathrm{Vs}^{-1}\right) v^{1 / 2}-2.87 \mu \mathrm{A}, \mathrm{R}=0.99 \\
\mathrm{I}_{\mathrm{pa}(\mathrm{Cys} / \mathrm{Au} / \mathrm{MoS} 2 / \mathrm{FTO})=}\left(8.46 \times 10^{-4} \mathrm{~A} \mathrm{Vs}^{-1}\right) v^{1 / 2} \\
+8.64 \mu \mathrm{A}, \mathrm{R}
\end{aligned}
$$$$
=0.99
$$

$\mathrm{I}_{\mathrm{pa}(\mathrm{Ab} / \mathrm{Cys} / \mathrm{Au} / \mathrm{MoS} 2 / \mathrm{FTO})}$

$$
=\left(7.23 \times 10^{-4} \mathrm{~A} \mathrm{Vs}^{-1}\right) v^{1 / 2}-0.01 \mu \mathrm{A}, \mathrm{R}=0.99
$$

$\mathrm{I}_{\mathrm{pa}(\mathrm{Vit} \mathrm{D} / \mathrm{Ab} / \mathrm{Cys} / \mathrm{Au} \text { MoS2/FTO) }}$

$$
=\left(5.54 \times 10^{-4} \mathrm{~A} \mathrm{Vs}^{-1}\right) v^{1 / 2}+10.8 \mu \mathrm{A}, \mathrm{R}=0.99
$$

By incorporating above values in Eq. (1), the electro-active surface area was obtained. The electro-active surface area obtained at each modification step was $\mathrm{MoS}_{2} / \mathrm{FTO}\left(0.12 \mathrm{~cm}^{2}\right)$, $\mathrm{Au} / \mathrm{MoS}_{2} / \mathrm{FTO}\left(0.31 \mathrm{~cm}^{2}\right), \mathrm{Cys} / \mathrm{Au} / \mathrm{MoS}_{2} / \mathrm{FTO}\left(0.23 \mathrm{~cm}^{2}\right)$, $\mathrm{Ab} / \mathrm{Cys} / \mathrm{Au} / \mathrm{MoS}_{2} / \mathrm{FTO}\left(0.19 \mathrm{~cm}^{2}\right)$, and $\mathrm{Vit} \mathrm{D} / \mathrm{Ab} / \mathrm{Cys} / \mathrm{Au} /$ $\mathrm{MoS}_{2} / \mathrm{FTO}\left(0.15 \mathrm{~cm}^{2}\right)$. It is notable that there was significant increase in the electro-active surface area of $\mathrm{Au} / \mathrm{MoS}_{2} / \mathrm{FTO}$ electrode $\left(0.31 \mathrm{~cm}^{2}\right)$ as compared to the $\mathrm{MoS}_{2} / \mathrm{FTO}$ electrode $\left(0.12 \mathrm{~cm}^{2}\right)$, signifying the superior electrocatalytic property of $\mathrm{Au} / \mathrm{MoS}_{2}$ hybrid.

\section{Electrochemical detection of $\mathbf{2 5}(\mathrm{OH}) \mathrm{D}_{3}$}

DPV response of the immunosensor incubated with increased concentrations of target $25(\mathrm{OH}) \mathrm{D}_{3}\left(1 \mathrm{pg} \mathrm{mL}^{-1}\right.$ to $\left.1 \mu \mathrm{g} \mathrm{mL}^{-1}\right)$ revealed an inversely proportional dependence of peak current value on the concentration of target $25(\mathrm{OH}) \mathrm{D}_{3}$ (Fig. 4a). The DPV response of bare immunoelectrode, i.e., in the absence of the target, was also recorded. Figure $4 \mathrm{~b}$ shows the variation of peak current value with the concentration of $25(\mathrm{OH}) \mathrm{D}_{3}$ in $\mathrm{pg}$ $\mathrm{mL}^{-1}$. The biosensor presented a linear response within $1 \mathrm{pg} \mathrm{mL}^{-1}$ to $100 \mathrm{ng} \mathrm{mL}^{-1} 25(\mathrm{OH}) \mathrm{D}_{3}$ concentration. Also, the immunosensor exhibits a linear response even for a narrow range of $25(\mathrm{OH}) \mathrm{D}_{3}$ concentration $\left(1-100 \mathrm{pg} \mathrm{mL}^{-1}\right.$ ) (inset of Fig. 4b). Further, a calibration plot was drawn between the peak current value and the log of concentration of $25(\mathrm{OH}) \mathrm{D}_{3}$ (Fig. 4c). Equation (9) represents the linear regression equation representing the calibration plot with a regression coefficient of -0.9 .

$Y=\left(-3.6 \times 10^{-5}\right) X+6.5 \times 10^{-4}$

Here, $\mathrm{Y}$ represents the peak current value in $\mathrm{A}$; $\mathrm{X}$ is the $\log$ (concentration of $25(\mathrm{OH}) \mathrm{D}_{3}$ in $\mathrm{pg} \mathrm{mL}^{-1}$ ). From the linear regression equation, the sensitivity was calculated by dividing the slope of calibration curve with electro-active surface area of the electrode and the value comes out to be $189 \mu \mathrm{A}\left[\log \left(\mathrm{pg} \mathrm{mL}^{-1}\right)\right]^{-1} \mathrm{~cm}^{-2}$. To find the theoretical limit of detection of the immunosensor, the following formula was used:

$L O D=3 \times S D / m$

Here, SD is the standard deviation of blank electrode sig$\mathrm{nal}$, and $\mathrm{m}$ is the slope of the calibration plot. By incorporating the values in Eq. (10), the theoretical limit of detection obtained was $0.38 \mathrm{pg} \mathrm{mL}^{-1}$. Table 1 shows the comparison of the present work with the already reported literature related to biosensor for vitamin $\mathrm{D}$ detection.

\section{Reproducibility, selectivity, and stability of electrochemical immunosensor}

Figure 5 a shows the reproducibility study of the $\mathrm{Ab} / \mathrm{Cys} / \mathrm{Au} /$ $\mathrm{MoS}_{2} /$ FTO electrodes for $1 \mathrm{ng} \mathrm{mL}^{-1}$ and $10 \mathrm{ng} \mathrm{mL}^{-1}$ concentration of $25(\mathrm{OH}) \mathrm{D}_{3}$. The relative standard deviation (RSD) obtained was $4.77 \%$ and $1.89 \%$ for $1 \mathrm{ng} \mathrm{mL}^{-1}$ and $10 \mathrm{ng} \mathrm{mL}^{-1}$ concentration of $25(\mathrm{OH}) \mathrm{D}_{3}$, respectively, indicating the minimal variation in electrode preparation and performance. The shelf life of the immunosensor was estimated by taking DPV response of immunoelectrode consecutively after an interval of 7 days for 35 days. It was observed that the immunosensor retained its $90.3 \%$ current response after 28 days and $85.7 \%$ current response after 35 days (Fig. 5b). Hence, the biosensor has an acceptable shelf life of 28 days.

Further, the possible interference of the different biomolecules in electrochemical signal of $25(\mathrm{OH}) \mathrm{D}_{3}$ was assessed. The results represent a considerable decrease in the peak current value of immunoelectrode after incubation with $25(\mathrm{OH}) \mathrm{D}_{3}$ as compared to the blank (without target), implying the formation of antibody-antigen immune complex. The peak current value obtained from the DPV response of $25(\mathrm{OH}) \mathrm{D}_{3}$ mixed with glucose, uric acid, cholesterol, and oxalic acid was almost similar to the response of $25(\mathrm{OH}) \mathrm{D}_{3}$ (Fig. $5 \mathrm{c}$ ); hence, there was no interference of aforementioned biomolecules towards the electrochemical measurement. On the other hand, a 
relative decrease in the peak current value by $15 \%$ was observed in the case of $25(\mathrm{OH}) \mathrm{D}_{2}$. This might be due to the interaction of $\mathrm{Ab}-25(\mathrm{OH}) \mathrm{D}_{3}$ with $25(\mathrm{OH}) \mathrm{D}_{2}$, because of the structural similarity of $25(\mathrm{OH}) \mathrm{D}_{2}$ with $25(\mathrm{OH}) \mathrm{D}_{3}$. Since both $25(\mathrm{OH}) \mathrm{D}_{2}$ and $25(\mathrm{OH}) \mathrm{D}_{3}$ contributes towards the total vitamin D status [6], thus, the $\mathrm{Ab} / \mathrm{Cys} / \mathrm{Au} / \mathrm{MoS}_{2} / \mathrm{FTO}$ immunoelectrode could be selectively and efficiently utilized to assess the total vitamin D status.

\section{Spike in studies}

Figure 6 a represents the DPV response of the immunosensor incubated with human serum spiked with various concentrations of $25(\mathrm{OH}) \mathrm{D}_{3}\left(1,10,10^{2}, 10^{3}\right.$, and $\left.10^{4} \mathrm{pg} \mathrm{mL}^{-1}\right)$. The peak current value obtained was noted, and a calibration plot of DPV response of spiked samples was obtained (Fig. 6b). The results obtained were compared with the standard calibration plot, and the recovery percentage was calculated. The immunosensor exhibits reliable performance towards spiked human serum sample with recovery $\%$ ranging from 95.1 to $102 \%$ and RSD value within 1.15-3.22\% (Table 2). Hence, the immunosensor could be efficiently utilized for the real sample analysis.

\section{Conclusions}

An electrochemical biosensor based on antibodies has been developed for the estimation of $25(\mathrm{OH}) \mathrm{D}_{3}$. The Au NP-supported $\mathrm{MoS}_{2}$ template has emerged as a stable and robust platform for the efficient binding of antibody onto the electrode surface. The in situ growth of Au NPs onto the $\mathrm{MoS}_{2}$ film greatly improved the conductivity of the biosensor and, hence, the sensitivity and LOD. Also, the SAM of cysteamine on the gold surface provides an opportunity for robust chemical binding of antibody rather than the weak physical adsorption, which impart additional strength to the biosensor as reflected in high storage stability of immunosensor. Furthermore, the biosensor was able to detect concentration as low as $0.38 \mathrm{pg} \mathrm{mL}^{-1}$, which comfortably meets the clinical requirement for the estimation of $25(\mathrm{OH}) \mathrm{D}_{3}$. The immunosensor has various points of merit such as fast response time, high selectivity, adequate reproducibility, and stability. In addition to this, the immunosensor responded well with the spiked human serum samples with high recoveries which support its potential applicability in clinical analysis. However, the selectivity and stability can further be improved by using aptamers as biorecognition molecules. Also, other conductive nanocomposites could also be explored to enhance the performance factors such as response time, sensitivity, and LOD.

Supplementary Information The online version contains supplementary material available at https://doi.org/10.1007/s00604-021-04862-6.
Acknowledgements We highly acknowledge SAIF/CIL, Panjab University Chandigarh, for providing us with the facility of FESEM and XRD. Authors are also grateful to Dr. Suman Singh [Central Scientific Instruments Organisation (CSIR-CSIO), Chandigarh] for helping us with the contact angle study.

Code availability Not applicable.

Author contribution Conceptualization, writing-original draft and methodology: AK; formal analysis and investigation: SR; data curation and validation: $A B$; resources and supervision: $G R C$; funding acquisition, supervision, and writing — review and editing: NP.

Funding This work was supported by the Department of Science and Technology [DST-Purse II], University Grants Commission-Special Assistance Programme (UGC-SAP) [F.4-7/2015/DRS-III (SAP-II)] and Department of Science and Technology-Science and Engineering Research Board sponsored project [EEQ/2017/000239].

Data availability All data generated or analyzed during this study are included in this published article and its supplementary material file.

\section{Compliance with ethical standards}

Conflict of interest The authors declare no competing interests.

\section{References}

1. Zmijewski MA (2019) Vitamin D and human health. Int J Mol Sci 20:145

2. Chang S, Lee H (2019) Vitamin D and health - the missing vitamin in humans. Pediatr Neonatol 60:237-244

3. Ilie PC, Stefanescu S, Smith L (2020) The role of vitamin D in the prevention of coronavirus disease. Aging Clin Exp Res 32:11951198

4. Pilz S, Zittermann A, Trummer C, Theiler-Schwetz V, Lerchbaum E, Keppel MH, Grübler MR, März W, Pandis M (2019) Vitamin D testing and treatment: a narrative review of current evidence. Endocr Connect 8:27-43

5. Shah I, Akhtar MK, Hisaindee S, Rauf MA, Sadig M, Ashraf SS (2018) Clinical diagnostic tools for vitamin D assessment. J Steroid Biochem Mol Biol 180:105-117

6. Stokes CS, Lammert F, Volmer DA (2018) Analytical methods for quantification of vitamin D and implications for research and clinical practice. Anticancer Res 38:1137-1144

7. Altieri B, Cavalier E, Bhattoa HP, Pérez-López FR, López-Baena MT, Pérez-Roncero GR, Chedraui P, Annweiler C, Casa SD, Zelzer S, Herrmann M, Faggiano A, Colao A, Holick MF (2020) Vitamin D testing: advantages and limits of the current assays. Eur J Clin Nutr 74:231-247

8. Carlucci L, Favero G, Tortolini C, Fusco MD, Romagnoli E, MinisolaS MF (2013) Several approaches for vitamin D determination by surface plasmon resonance and electrochemical affinity biosensors. Biosens Bioelectron 40:350-355

9. Singh RJ (2008) Are clinical laboratories prepared for accurate testing of 25-hydroxy vitamin D? Clin Chem 54:221-223

10. Farrell C, Soldo J, Williams P, Herrmann M (2012) 25 Hydroxyvitamin D testing: challenging the performance of current automated immunoassays. Clin Chem Lab Med 50:1953-1963

11. Golichenari B, Nosrati R, Farokhi-Fard A, Maleki MF, Hayat SMG, Ghazvini K, Vaziri F, Behravan J (2019) Electrochemical- 
based biosensors for detection of Mycobacterium tuberculosis and tuberculosis biomarkers. Crit Rev Biotechnol 39:1056-1077

12. Sarkar T, Bohidar HB, Solanki PR (2018) Carbon dots-modified chitosan based electrochemical biosensing platform for detection of vitamin D. Int J Biol Macromol 109:687-697

13. Chauhan D, Gupta PK, Solanki PR (2018) Electrochemical immunosensor based on magnetite nanoparticles incorporated electrospun polyacrylonitrile nanofibers for vitamin- $\mathrm{D}_{3}$ detection. Mater Sci Eng C 93:145-156

14. Chauhan D, Kumar R, Panda AK, Solanki PR (2019) An efficient electrochemical biosensor for vitamin-D3 detection based on aspartic acid functionalized gadolinium oxide nanorods. J Mater Res Technol 8:5490-5503

15. Kaur A, Kapoor S, Bharti A, Rana S, Chaudhary GR, Prabhakar N (2020) Gold-platinum bimetallic nanoparticles coated 3(aminopropyl)triethoxysilane (APTES) based electrochemical immunosensor for vitamin D estimation. J Electroanal Chem 873: 114400

16. Baek SH, Roh J, Park CY, Kim MW, Shi R, Kailasa SK, Park TJ (2020) Cu-nanoflower decorated gold nanoparticles-graphene oxide nanofiber as electrochemical biosensor for glucose detection. Mater Sci Eng C 107:110273

17. Su S, Hao Q, Yan Z, Dong R, Yang R, Zhu D, Chao J, Zhou Y, Wang L (2019) A molybdenum disulfide@methylene blue nanohybrid for electrochemical determination of microRNA-21, dopamine and uric acid. Microchim Acta 186:607

18. Govindasamy M, Chen SM, Mani V, Akilarasan M, Kogularasu S, Subramani B (2017) Nanocomposites composed of layered molybdenum disulfide and graphene for highly sensitive amperometric determination of methyl parathion. Microchim Acta 184:725-733

19. Govindasamy M, Chen SM, Mani V, Devasenathipathy R, Umamaheswari R, Santhanaraj KJ, Sathiyan A (2017) Molybdenum disulfide nanosheets coated multiwalled carbon nanotubes composite for highly sensitive determination of chloramphenicol in food samples milk, honey and powdered milk. J Colloid Interface Sci 485:129-136

20. Zhang Y, Li X, Li D, Wei Q (2020) A laccase based biosensor on AuNPs-MoS $\mathrm{S}_{2}$ modified glassy carbon electrode for catechol detection. Colloids Surf B: Biointerfaces 186:110683

21. Ma C, Ma Y, Sun Y, Lu Y, Tian E, Lan J, Li J, Ye W, Zhang H (2019) Colorimetric determination of $\mathrm{Hg}^{2+}$ in environmental water based on the $\mathrm{Hg}^{2+}$ stimulated peroxidase mimetic activity of $\mathrm{MoS}_{2}-$ $\mathrm{Au}$ composites. J Colloid Interface Sci 537:554-561
22. Ji R, Chen S, Xu W, Qin Z, Qiu JF, Li CR (2018) A voltammetric immunosensor for clenbuterol based on the use of a $\mathrm{MoS}_{2}-\mathrm{AuPt}$ nanocomposite. Microchim Acta 185:209

23. Sreeprasad TS, Nguyen P, Kim N, Berry V (2013) Controlled, defect-guided, metal-nanoparticle incorporation onto $\mathrm{MoS}_{2}$ via chemical and microwave routes: electrical, thermal, and structural properties. Nano Lett 13:4434-4441

24. Mani V, Govindasamy M, Chen SM, Subramani B, Sathiyan A, Merlin JP (2017) Determination of folic acid using Graphene/ molybdenum disulfide nanosheets/gold nanoparticles ternary composite. Int J Electrochem Sci 12:258-267

25. Su S, Cao W, Liu W, Lu Z, Zhu D, Chao J, Weng L, Wang L, Fan C, Wang L (2017) Dual-mode electrochemical analysis of microRNA-21 using gold nanoparticle-decorated $\mathrm{MoS}_{2}$ nanosheet. Biosens Bioelectron 94:552-559

26. Awotunde O, Okyem S, Chikoti R, Driskell JD (2020) Role of free thiol on protein adsorption to gold nanoparticles. Langmuir 36 : 9241-9249

27. Ran F, Liu H, Wang X, Guo Y (2017) A novel molybdenum disulfide nanosheet self-assembled flower-like monolithic sorbent for solid-phase extraction with high efficiency and long service life. J Chromatogr A 1507:18-24

28. Rana S, Bharti SS, Bhatnagar A, Prabhakar N (2020) Gold-silver core-shell nanoparticle-based impedimetric immunosensor for detection of iron homeostasis biomarker hepcidin. Microchim Acta 187:626

29. Bard AJ, Faulkner LR (1980) Electrochemical methods: fundamentals and applications. Wiley, New York

30. Veeramalai CP, Li F, Liu Y, Xu Z, Guo T, Kim TW (2016) Enhanced field emission properties of molybdenum disulphide few layer nanosheets synthesized by hydrothermal method. Appl Surf Sci 389:1017-1022

31. Feng W, Chen L, Qin M, Zhou X, Zhang Q, Miao Y, Qiu K, Zhang $\mathrm{Y}, \mathrm{He} \mathrm{C}$ (2015) Flower-like PEGylated $\mathrm{MoS}_{2}$ nanoflakes for nearinfrared photothermal cancer therapy. Sci Rep 5:17422

32. Yaraki MT, Tayebi M, Ahmadieh M, Tahriri M, Vashaee D, Tayebi L (2017) Synthesis and optical properties of cysteamine-capped $\mathrm{ZnS}$ quantum dots for aflatoxin quantification. J Alloys Compd 690:749-758

Publisher's note Springer Nature remains neutral with regard to jurisdictional claims in published maps and institutional affiliations. 